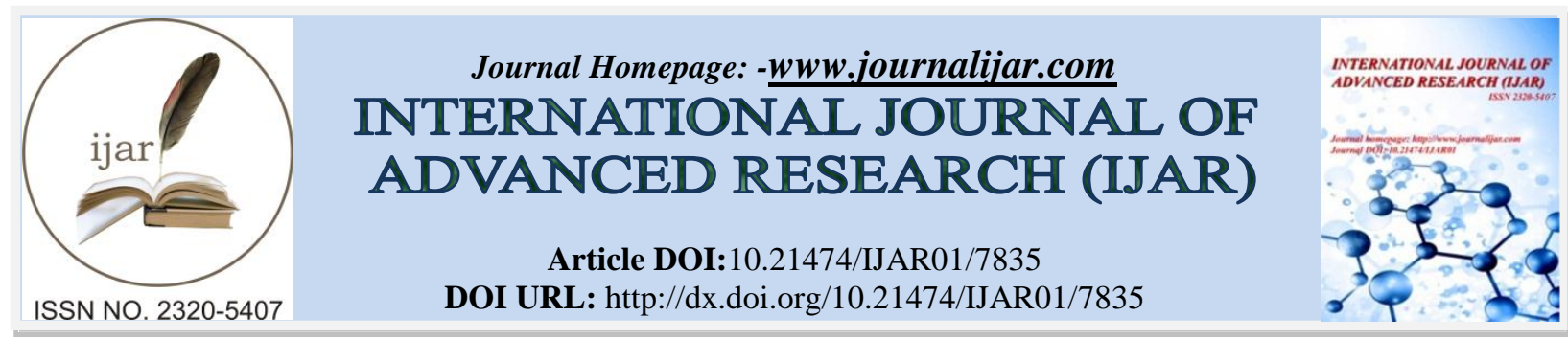

RESEARCH ARTICLE

\title{
WEB-BASED INTELLECTUAL CAPITAL DISCLOSURES: AN EXPLORATORY STUDY.
}

\section{Dyna Rachmawati, Cicilia Erna Susilawati, Hendra Wijaya and Mudjilah Rahayu.} Faculty of Business, Widya Mandala Catholic University of Surabaya.

\section{Manuscript Info}

Manuscript History

Received: 7 August 2018

Final Accepted: 9 September 2018

Published: October 2018

Keywords:-

Intellectual capital, internal capital, external capital, human capital, and webbased disclosure.

\begin{abstract}
Background: Previous studies of intellectual capital disclosure use the annual report as a source of information. The annual report is considered to be objective because the company only delivers certain information. Therefore, this study aims to change the source used as data collection.

Research method: This study uses the company's official website and online business media to identify the intellectual capital disclosure level.

This study uses exploratory study. It explores the elements of intellectual capital that is often disclosed by both companies through its official website and online business media as an independent party in the period January - July 2017. This study uses open companies included in the LQ 45.

Results: The results show that internal capital is the component of the most disclosed company in its official website and online business media. External capital is in second position and the last one is human capital. The results also indicate that the internal capital element most widely disclosed in the official website is corporate culture, while in the online business media reveals management process more.

Conclusion: Overall, the results of this study recommend the alternative of sources other than annual report to measure the disclosure of intellectual capital index.
\end{abstract}

Copy Right, IJAR, 2018,. All rights reserved.

\section{Introduction:-}

Indonesia's global competitiveness index (GCI) at rank $41^{\text {st }}$ in 2016. The ranking is dropped down, as in 2015 Indonesia GCI ranking is at $37^{\text {th }}$ in the world.

This study is funded by Indonesian Ministry of Research, Technology and Higher Education by Contract No. 115K/WM01.5/N/2018

The World Economic Forum (WEF)'s report in period 2016-2017 states several reasons for the downgrade of Indonesia's GCI due to the downgrading of Indonesia's ratings on several indicators that are the parameters of GCI.First reason is the decline of Indonesia's health and education rating to $100^{\text {th }}$ (previously ranked $80^{\text {th }}$ ). The decline in rank is in line with the decline in the rank of human development index (HDI) at the $113^{\text {th }}$ position previously at the $110^{\text {th }}$ position in 2015 . This is due to the unequal opportunity to get health care and education 
throughout the country. Gender differences are also still a problem in the penetration of education in Indonesia. Second reason is the downgrading of technological readiness ratings at $91^{\text {th }}$ position. The level of penetration of information communication and technology (ICT) is still uneven. Internet usage in Indonesia is still a fifth of the population and there is only 1 broadband connection that connects 100 people. The downgrade of Indonesia's GCI is also due to the decline of the global innovation index (GII). Indonesia's GII in 2015 amounted to 29.8 and in the year 2016 slightly decreased to 29.1. GII shows how much the level of output in the form of knowledge, technology, and creativity. This index indicates the country's ability to increase its economic growth. Innovation is one form of intangible assets that can provide competitive advantage.

Innovation is one of intellectual capital's component especially renewal capital. Lin et al (2014) show that Indonesia's renewal capital has a low score ranging from 1.15 to 2.06 in the period $2005-2010$. The score is lower than Malaysia which has $2.11-2.26$ in the same period. Lin et al (2014) also show that intellectual capital in Indonesia is lower than Malaysia in the period 2005 - 2010. Nevertheless, Indonesia has the potential to increase its intellectual capital.

Intellectual capital of Indonesian companies has value amounted to its residual value (Rachmawati and Susilawati, 2008). Residual value is earnings minus normal return. Normal return is obtained from the book value at the beginning of the period multiplied by the expected return expected by the investor. Rachmawati and Susilawati use 5 models to measure intellectual capital. The results show that the model with residual value is the best model compared to the other four models. This indicates that the value of intellectual capital in Indonesia is equal to its residual value. Residual value is a model of intellectual capital measurement using the methodology of return on assets (ROA) (Jurczak, 2008). In addition to residual values, VAIC ${ }^{\mathrm{TM}}$ is a measurement model that uses the ROA methodology. VAIC $^{\mathrm{TM}}$ is more popular than the residual value to measure intellectual capital because of the ease of data access that is using financial statements. VAIC ${ }^{\mathrm{TM}}$ is developed by Pulic in 1999. VAIC ${ }^{\mathrm{TM}}$ aims to measure the added value contributed by intellectual capital. Despite its advantages, VAIC ${ }^{\mathrm{TM}}$ has also received much criticism from experts (Fijalkowska, 2014; Bakhsa, Afrazeh, and Esfahanipour, 2017). Criticism is more directed to the use of financial statements as a source of data is a form of simplification in calculating intellectual capital. Despite much criticism, VAIC ${ }^{\mathrm{TM}}$ is the most widely used method of measurement in intellectual capital studies. And the results are inconsistent (Maditinoset al, 2011; Chu et al, 2011; Al Musali and Ismail, 2014; Berzkalne and Zelgalve, 2014; Al Musali and Ismail, 2014; Nuryaman, 2015; Hayati, Yurniati and Putra, 2015; Ariff, van Zijl, and Islam, 2015; Ozkan, Cakan and Kayacan, 2016; Chizariet al, 2016).

An alternative measurement of intellectual capital is the scorecard methodology (SC method) (Jurczak, 2008). SC method accommodates non-financial performance measures, such as the model developed by Guthrie and Petty (2000). Guthrie and Petty developed indicators to measure the three components of intellectual capital including internal capital, external capital and human capital. These indicators are used as guidelines for measuring the value of intellectual capital scores. There are two approaches to determining the score. First, a score of 1 is given to the company that discloses those indicators in its annual report, and 0 if there is no information related to those indicators. The number of disclosure scores made by the company divided by the total score that should be disclosed by the company. The figure shows the level of intellectual capital disclosure. This method is called a checklist. Second, the number of keyword indicators on each component of intellectual capital appearing in the annual report. The more these keywords appear in the annual report the more important the indicators on the components of intellectual capital for the company. This method is called content analysis (CA). Checklist and CA methods contain elements of subjectivity. Nevertheless, the use of SC methods is able to identify intangible assets that are not reported by financial statements.

VAIC $^{\mathrm{TM}}$ and intellectual capital disclosure (ICD) are the most widely used measurements in intellectual capital studies. Rachmawati, Antonio, and Suwidji (2017) find that VAIC ${ }^{\mathrm{TM}}$ has no value relevance when ICD is included in the model. The result of this study indicates that ICD is a stronger proxy for intellectual capital than VAIC ${ }^{\mathrm{TM}}$. Therefore, this study uses ICD to measure intellectual capital. Previous studies used annual reports to calculate ICD. The annual report is not an objective source of data, because companies only communicate the information they want to convey to the public (Abeysekera, 2006; Dumay and Cai, 2015).

This research attempts to respond to Abeysekera (2006) and Dumay and Cai (2015) arguments regarding the use of annual reports as a non-objective data source, so that this study use data sources from official websites and online business media. Online business media used are Kontan, SWA, Warta Ekonomi, and Bisnis Indonesia. Online 
business media is sourced from third parties. Both sources are expected to increase objectivity in measuring intellectual capital by using the SC method (Jurczak, 2008; Dumay and Cai, 2015). The intellectual capital component used in this study is based on the conceptual framework of Guthrie and Ricceri (2002) originally developed for intellectual capital. The conceptual framework is most widely used in previous studies (Dumay and Cai, 2015). The use of conceptual framework in this study aims to find the generalization of results. Guthrie and Ricceri divide intellectual capital into three major components, namely: internal capital, external capital, and human capital. This study aims to identify the elements of intellectual capital based on the conceptual framework of Guthrie and Ricceri (2002) which is often expressed by public companies on its official website, as well as elements of intellectual capital that are often reported in online business media.

\section{Literature review and hypotheses development:-}

\section{Conceptual framework and intellectual capital measurement methods}

Alhusban and Rigsdell (2014) used a "derivative" or ancestry approach to studying the development of intellectual capital conceptual framework. The most widely used conceptual framework in the literature study is the framework developed by Luthy (1998), Sveiby (2001, 2010), and Guthrie and Ricceri (2002).

Luthy (1998) defines that intellectual capital is something that is knowledge-based and internalized in the organization to give value added. Luthy uses two methods to measure intellectual capital:

1. Evaluation of each component, including unit of measurement of each component of intellectual capital appropriately. Intellectual capital is divided into 3 components: customer capital, structural capital and human capital (Edvinson and Malone, 1997). Each component has several elements. Example: one of the measurement elements in the customer capital component is the market share; one element in structural capital component is patent value; one of the elements in the human capital component is the number of jobs completed by the employees according to their competence.

2. Measurement of intellectual capital financially. This method indicates the outcome or achievement of intellectual capital empowerment. The methods used are Tobin's Q, market to book value (MBV), economic value added (EVA).

Sveiby (2001) andJurczak (2008) have identified 21 methods of intellectual capital measurement which then increased to 42 methods in 2010 (Sveiby, 2010). The methods of measurement are classified into four major groups (Sveiby, 2001; Jurczak, 2008; Sveiby, 2010; Mohamed, 2017), as below:

1. Return on assets (ROA) methods. This method uses data from financial statements. In principle this method calculates the level of investment effectiveness of intangible assets or intellectual capital. Methods of measuring intellectual capital included in this group are economic value added $\left(\mathrm{EVA}^{\mathrm{TM}}\right)$, human resources cost and accounting (HRCA), calculated intangibles values, knowledge capital earnings, value added intellectual coefficient (VAIC ${ }^{\mathrm{TM}}$ ) and accounting for the futures.

2. Market capitalization methods (MCM). This method uses market data to calculate the difference between the book value reported in the financial statements and the market value. The difference is a goodwill that is considered as intellectual capital. The methods of measuring intellectual capital included in this group are Tobin's Q ratio, investor assigned market's value (IAMV ${ }^{\mathrm{TM}}$ ) and market to book value (MBV).

3. Direct intellectual capital methods (DICM). This method is used to estimate how much the value of intellectual capital owned by the company. Estimates are performed by: (1) identifying the components of intellectual capital, (2) estimating the investment value of each component, and then (3) determining the index of intellectual capital based on the estimated value of the components of intellectual capital. The methods of measuring intellectual capital included in this group are technology brokerage, citation weighted patents, the value explorer ${ }^{\mathrm{TM}}$, intellectual assets valuation and total value creation $\left(\mathrm{TVC}^{\mathrm{TM}}\right)$.

4. Scorecard methods (SC methods). This method identifies the indicators of each component of intellectual capital. It is then reported in the form of a scorecard. The methods of measuring intellectual capital included in this group are human capital intelligence, scandianavigator ${ }^{\mathrm{TM}}$, value chain scoreboard ${ }^{\mathrm{TM}}$, intangible assets monitors, intellectual capital navigator and intellectual capital index (IC index ${ }^{\mathrm{TM}}$ ), value creation index and balanced scorecard (BSC).

Guthrie and Ricceri (2002) have examined four classifications made by Sveiby (2001). The results have implications that there are two major group methods of measuring intellectual capital: intellectual capital's (IC) stock and IC flow. IC stock is related to financial-based measurement. IC flow is concerned with measuring the knowledge resources used by the firm for value creation. IC flow includes three components of intellectual capital (Guthrie et 
al., 2004): internal capital, external capital and human capital. The intellectual capital components of Guthrie et al (2004) are derived from Sveiby's conceptual framework (Sveiby, 1997).Internal capital includes patents, concepts, models, information systems and administrative systems. Internal capital is created by individuals within the organization and belongs to the organization. External capital includes relationships with consumers and suppliers, brand names, trademarks, reputation and image. External capital can be in the form of legal right to brand and trademark. While the relationship between the company and the consumer shows a strong bond between the company and its customers. This means that the company is able to meet the needs of consumers. Human capital includes the capabilities and competencies of individuals in the organization so as to produce intangible assets.

\section{Intellectual capital disclosure}

Intellectual capital disclosure is one of the approaches used to measure intellectual capital, as intellectual capital is an intangible asset that failed to be reported by accounting. The use of intellectual capital disclosure began to be investigated by Guthrie and Petty (2000). Guthrie and Petty use annual reports as sources to identify intellectual capital disclosure levels. Subsequent studies began to refer to research Guthrie and Petty. Cuozzoet al (2017) conducted a literature study of 246 research articles on intellectual capital disclosure published in the Journal of Intellectual Capital (JIC), Journal of Human Resources Costing and Accounting (JHRCA), the Australian Accounting Review (AAR), the Accounting Auditing and Accountability Journal (AAAJ), Accounting Forum (AF), Accounting Organizations and Society (AOS), British Accounting Review (BAR), Critical Perspectives on Accounting (CPA), and European Accounting Research (MAR) in the period 2015 - 2016. Those studies indicate that the disclosure of intellectual capital has benefits for investors. Companies that disclose intellectual capital more widely considered able to empower the organization in creating added value.

The disclosure of intellectual capital in previous studies using content analysis (CA) method is to identify intellectual capital disclosure level. CA is a research technique for analyzing communication, by describing the information content communicated by the organization in an annual report. Harmonization of report types used as a data source by research by CA method is important. And harmonization of the intellectual capital components used by research with the CA method. This harmonization aims to be able to compare the results of intellectual capital disclosure research (Castilla-Polo and Ruiz-Rodriguez, 2017). However, such harmonization cannot be achieved as different countries are going to have different regulations regarding the annual report.

Annual report is a source for research with CA method. Annual report is not an objective source as the report often used by companies to inform certain information. Annual reports are used to provide information about what the company wants to say, thus giving the impression that the information is more promotional (Abeysekera, 2006; Dumay and Cai, 2015). Dumay and Cai state the need for breakthroughs using data sources in research by CA method, for example through the information available on the internet because it allows users to access information easily.

\section{Research method:-}

This study uses explorative method. The explorative method aims to explore the disclosure of elements in the intellectual capital component of the internet. The Internet is used as the primary source in this research responding to Dumay and Cai (2015). Sources of information from the internet used are the company's official website and online business media in period January - July 2017. The companies used as population are LQ45 companies in period February - July 2017. The exploratory results of these elements of intellectual capital are then identified which elements of intellectual capital are most frequently disclosed by companies and online business media. Intellectual capital disclosure in this study follows conceptual framework from Guthrie and Ricceri (2002) and then modified by Guthrie et al (2004). The framework is mostly used by previous studies on intellectual capital disclosure (Dumay and Cai, 2015). Table 1 below shows the three components of the intellectual capital based on framework by Guthrie et al (2004):

Table 1:-Intellectual Capital Components

\begin{tabular}{|l|l|l|l|l|l|}
\hline 1. & Internal capital (IC) & 2. & External capital (EC) & 3. & Human capital (HC) \\
\hline 1. & Intellectual property (IP) & 7. & Brands (Brand) & 14. & Employee (Empl) \\
\hline 2. & $\begin{array}{l}\text { Management philosophy } \\
\text { MPhil) }\end{array}$ & 8. & Customers (Cust) & 15. & Education (Ed) \\
\hline 3. & Corporate culture (CC) & 9. & Customer satisfaction $(\mathrm{CS})$ & 16. & Training (Train) \\
\hline 4. & Management processes & 10. & Company names $(\mathrm{CN})$ & 17. & Work-related knowledge \\
\hline
\end{tabular}




\begin{tabular}{|l|l|l|l|l|l|}
\hline & (MProc) & & & & (WR) \\
\hline 5. & $\begin{array}{l}\text { Information/networking } \\
\text { systems } \text { (NS) }\end{array}$ & 11. & Distribution channels (DC) & 18. & Entrepreneurial spirit (ES) \\
\hline 6. & Financial relations (FR) & 12. & Business collaborations (BC) & & \\
\hline & & 13. & Licensing agreements (LA) & & \\
\hline
\end{tabular}

Table 1 above is used as a guide to identify intellectual capital disclosure using content analysis method. Content analysis is a method of measurement based on the number of keywords that appear on the company's official website and online business media (Kontan, SWA, Bisnis Indonesia, and Warta Ekonomi).

\section{Results and discussions:-}

Internal capital is the most expressed component of intellectual capital both on the company's official website and online business media, while external capital is the second largest component of intellectual capital followed by human capital. The results of this study support Sharma and Kaur (2016). Sharma and Kaur find that internal capital is most disclosed on the company's official website, followed by external and human capital. Figure 1 below shows the comparative disclosure of intellectual capital components on companies' official website and online business media.

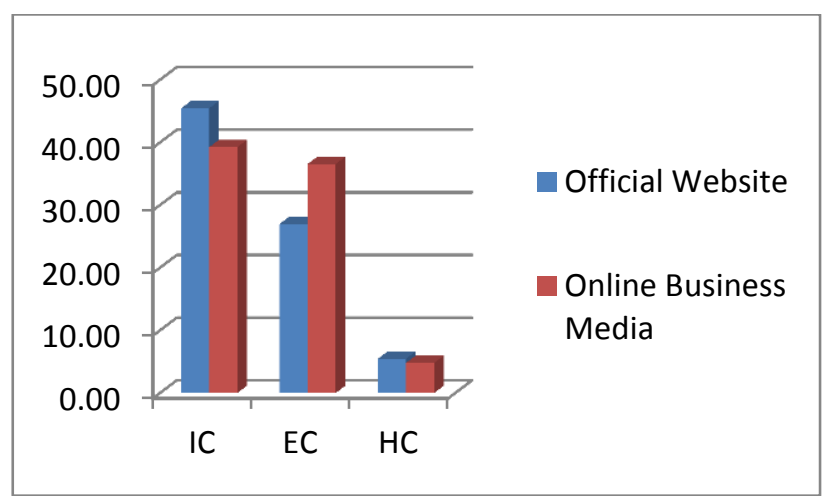

IC= internal capital, EC=external capital, $\mathrm{HC}=$ human capital

Figure 1:-intellectual capital on official website versusonline business media

Figure 1 shows that internal capital (IC) has the highest average rate both on official website and online business media, amounted 45 an 39 times. Official website contents internal capital more than online business media. The finding indicates that internal capital represents the conditions within the company that must be communicated to the public to reduce information asymmetry. On the other hand, the average rate of external capital (EC) on online business media (37 times) is higher than on official website (27). This implies that for online business media the external relationship is more important, especially regarding customers.

The average rate of human capital (HC) is the lowest both on official website and online business media. This indicates that human capital is still tacit and not yet operationalized.

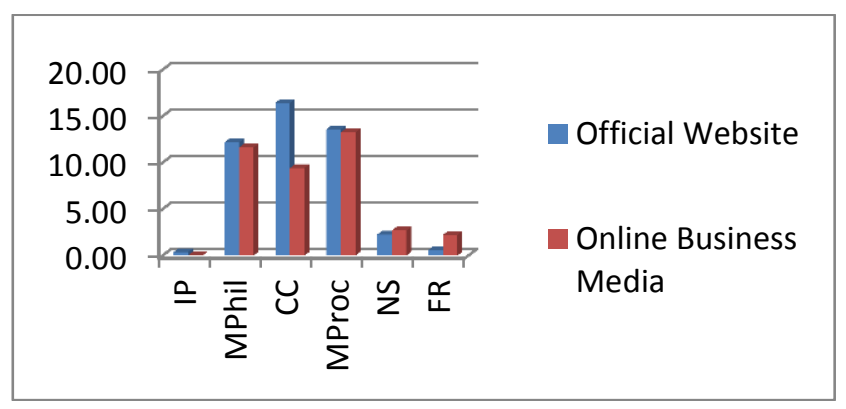

\footnotetext{
IP=intellectual property MPhil=management philosophy

$\mathrm{CC}=$ corporate culture $\quad$ MProc $=$ management process

$\mathrm{NS}=$ networking system $\mathrm{FR}=$ financial relations
} 
Figure 2:- internal capital on official website versus online business media

Figure 2 shows the elements of internal capital disclosed on official website and online business media. The highest average rate is corporate culture (CC) element on official website, while on online business media is management process (MProc). The findings indicate that for company, disclosing corporate culture is important as it is the foundation or the cause why the company has been existed.

Though for online business media, telling management process publicly is important as public has the right to know how the process within the company. The difference of the average rate of management process between official website and online business media is low. This means disclosure of process management on online business media is as important as on the company's official website.

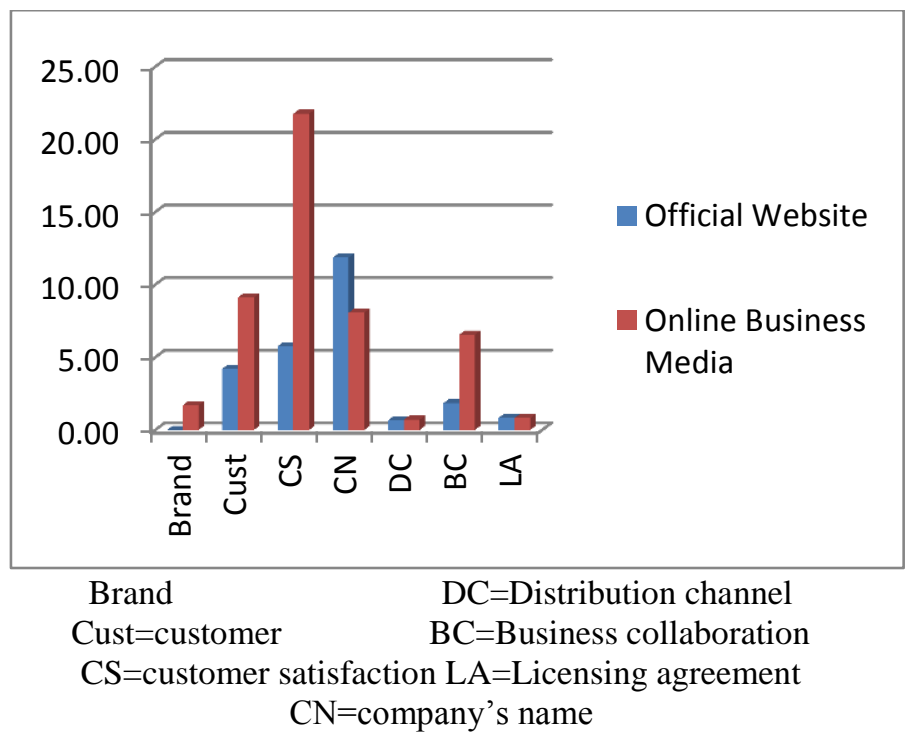

Figure 3:-external capital on official website versus online business media

Figure 3 shows that the elements of external capital both on official website and online business media. The average rate of customer satisfaction (CS) on online business media is the highest among other elements both on official website and online business media. This finding indicates that customer satisfaction is an important element of external capital. Online business media consider that customer satisfaction has to be informed publicly in order to describe the companies' effort to increase customer satisfaction.

On the other hand, company's name $(\mathrm{CN})$ is the highest element on official website. It implies that company has more focused on building company name as product quality guarantee.

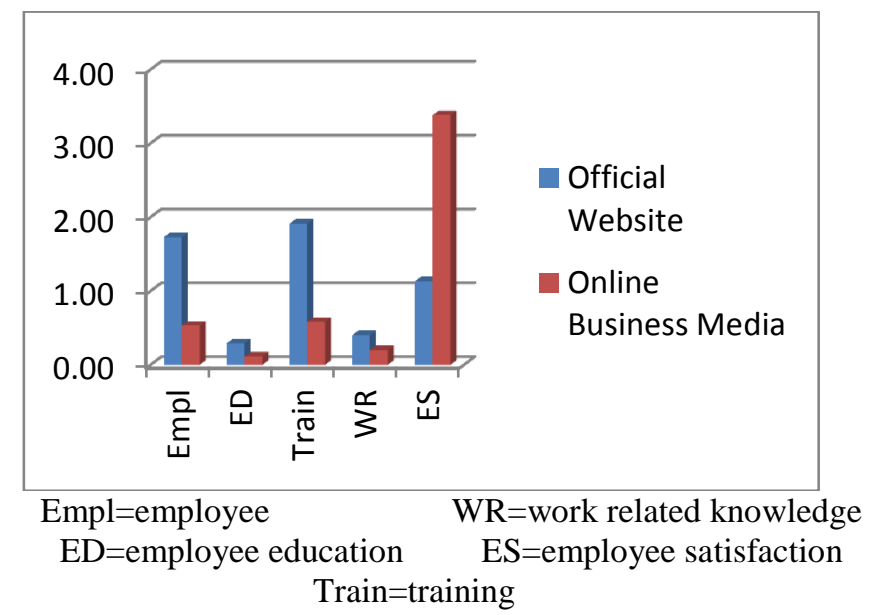

Figure 4:-human capital on official website versus online business media 
Figure 4 shows the elements of human capital disclosed on official website and online business media. The average rate of employee satisfaction (ES) on online business media is the highest among other elements both on online business media and official website. Employee satisfaction is the key to make company succeed. Unsatisfied employee promotes contra productive for the company. It suggests that company has to take care of their employee. On the other hand, training (TRAIN) is the element that has highest average rate on official website. It indicates that company has to train the employee according to the needs.

The findings of this study suggest that there is a slightly difference of disclosure on official website and online business media as mentioned before by Dumay and Cai (2015). This study also indicates that using company's official website as a source of data has the same objectivity with online business media. Further research on intellectual capital disclosure can use either company's official website or online business media.

\section{Conclusions and research limitations:-}

Overall, internal capital is the component of intellectual capital most widely disclosed both on the company's official website and online business media, followed by external capital and human capital. The level of disclosure on the company's official website has a higher average compared to online business media. This indicates that the company's official website is one of the means used by the company to do promotion. While the online business media tend to convey information related to customer satisfaction.

Customer satisfaction is the element with the highest average value of both the disclosure of the company's official website and online business media. This indicates the importance of customer satisfaction as intellectual capital.

This study is limited to exploring the components of intellectual capital and the elements that make up it. Further research needs to test that the level of disclosure of websites and online business media has the same benefit of information.

\section{References:-}

1. Abeysekera, I., (2006), the Project of Intellectual Capital Disclosure: Researching the Research, Journal of Intellectual Capital, Vol. 7, No. 1, $61-77$

2. Alhusban, M., danRagsdell, G., (2014), Bridging the Gap Between Intellectual Capital Models: An Ancestry/Chronology Approach, Prosiding 11th International Conference on Intellectual Capital, Knowledge Management and Organizational Learning, Sydney 6-7 November 2014, 477 - 487

3. Al-Musali, M.A.K, dan Ismail, K.N.I.K., (2014), Intellectual Capital and Its Effect on Financial Performance of Banks: Evidence from Saudi Arabia, Procedia Social and Behavioral Sciences, 164, 201- 2017

4. Amit, R. danSchoemaker, P.J.H., (1993), Strategic Assets and Organizational Rent, Strategic Management Journal, Vol. 14, $33-46$

5. Ariff, A.H.M, van Zijl, T., dan Islam, A., (2015), Intellectual Capital and Market Performance: The Case of Multinational R\&D and Firms in the US, Proceeding of the Asia Pacific Conference on Business and Social Sciences 2015 Kuala Lumpur (in partnership with The Journal of Developing Areas), 673 - 681

6. Bakhsa, A., Afrazeh, A., danEsfahanipour, A., (2017), A Criticsm on Value Added Intellectual Coefficient (VAIC) Model, International Journal of Computer Science and Network Security, Vol. 17, No. 6, 59 - 71

7. Barney J., (1991), Firm Resources and Sustained Competitive Advantage, Journal of Management, Vol. 17, No. $1,99-120$

8. Barney J., (2001), Is The Resource-Based "View" A Useful Perspective For Strategic Management Research? Yes, Academy of Management Review, Vol. 26, No. 1, 41 - 56

9. Barney J., Wright, M., Ketchen, D.J., (2001), the Resource-Based View of the Firm: Ten Years After 1991, Journal of Management, 27, $625-641$

10. Berzkalne, I., danZelgalve, E., (2014), Intellectual Capital and Company Value, Procedia Social and Behavioral Science, $110,887-896$

11. Chizari, M.H., Mehrjadi, R.Z., Sadrabadi, M.M., danMehrjadi, F.T., (2016), The Impact of Intellectual Capital of Pharmaceutical Companies Listed in Tehran Stock Exchange on Their Market Performance, Procedia Economic and Finance, 36, 291 - 300

12. Chu S.K.W., Chan K.H., Wu W.W.Y, (2011), Charting Intellectual Capital Performance of the Gateway to China, Journal of Intellectual Capital, Vol. 12 (2), $249-276$

13. Collis, D.J., (1994), Research Note: How Valuable Are Organizational Capabilities, Strategic Management Journal, Vol. 15, special Issue: Competitive Organizational Behavior, 143 - 152 
14. Connor, T., (2002), The Resources Based View of Strategy and Its Value to Practicing Managers, Strategic Change, 11, www.interscience.wiley.com

15. Cuozzo, B., Dumay, J., Palmaccio, M., dan Lombardi, R., (2017), Intellectual Capital Disclosure: a Structured Literature Review, Journal of Intellectual Capital, Vol. 18, No. 1, 9 - 28

16. Dumay J., danCai L., (2015), Using Content Analysis as a Research Methodology for Investigating Intellectual Capital Disclosure, Journal of Intellectual Capital, Vol. 16 (1), 121 - 155

17. Edvinsson, L. dan Malone M. S., (1997), Intellectual capital: The proven way to establish your company's real value by measuring its hidden brainpower, Piatkus

18. Fijalkowska, J., (2014), Value Added Intellectual Coeficient (VAICTM) as a Tool of Performance Measures, Entrepreneurhip and Management University of Social Sciences Publishing House, Vol. XV (1), $129-140$

19. Garanina, T., danDumay, J., (2017), Forward Looking Intellectual Capital Disclosure in IPO's Implications for Intellectual Capital and Integrated Reporting, Journal of Intellectual Capital, Vol. 18, No. 1, 128 - 148

20. Goebel V., (2015), Estimating a Measure of Intellectual Capital Value to Test Its Determinants, Journal of Intellectual Capital, Vol. 16 (1), $101-120$

21. Grant, R.M., (1991), the Resource-Based Theory of Competitive Advantage: Implications for Strategy, California Management Review, 33 (3), 114 - 135

22. Guthrie, J., dan Petty, R., (2000), Intellectual Capital: Australian Annual Reporting Practices, Journal of Intellectual Capital, Vol. 1, No. 3, $241-251$

23. Guthrie, J., danRicceri, F., (2002), Quantify Intellectual Capital: Measuring and Reporting to Demonstrate Value of KM to Stakeholder, Knowledge Management Australia, ProsidingBuilding and Improving on Knowledge Management Initiative for Commercial Proficiency, Sidney 4 December 2002

24. Guthrie, J., Petty, R., danRicceri, F., (2004), External Intellectual Capital Reporting: Contemporary Evidence from Hongkong and Australia, working paper in Management, Macquire Graduate School of Mangement, Sidney-Australia

25. Hayati, M., Yurniawati, dan Putra, A.R., (2015), The Effect of Intellectual Capital to Value Relevance of Accounting Information Based on PSAK Convergence of IFRS (Manufacturing Firms in Indonesia), Procedia Social and Behavioral Sciences, 211, $999-1007$

26. Hosseini, M.M., danSaleh, O., (2016), Designing a Model for Measuring and Analyzing the Relational Capital Using Factor Analysis: Case Study Ansar Bank, Journal of Intellectual Capital, Vol. 17, No. 4, 734 - 757

27. Jurczak J., (2008), Intellectual Capital Measurement Methods, Institute of Organization and Management in Industry, Vol 1(1), $37-45$

28. Lev, B., (2001), Intangibles: Management, Measurement, and Reporting, the Brookings Institution, Washington $\mathrm{DC}$

29. Lin, C.Y.Y., L. Edvinsson, J. Chen, and T. Beding, (2014), National Intellectual Capital and the Financial Crisis in Indonesia, Malaysia, the Philipines, and Thailand, Springer, New York

30. Long, L., Ing, H., Pey, D. dan Tsai, L., (2012), Human Capital Disclosure and Organizational Performance, Management Decision, Vol. 50, No. 10, 1790 - 1990

31. Luthy, D.H., (1998), Intellectual Capital and Its Measurement, Prosiding the Asian Pacific Interdisciplinary Research in Accounting (APIRA) Conference, Osaka

32. Maditinos, D., Chatzoudos, D., Tsairidis, C., Theriou, G., (2011), The Impact of Intellectual Capital on Firm's Market Value and Finanical Performance, Journal of Intellectual Capital, Vol. 12 (1), 132 - 151

33. Mohamed, I.A.H., (2017), Methods of Measuring Intellectual Capital and the Efficiency of Investment It: Advantages \& Disadvantages Analytical Comparative Study, Imperial Journal of Interdisciplinary Research, Vol. 3, No. 2, 1083 - 1092

34. Nuryaman, (2015), The Influence of Intellectual Capital on The Firm's Value with The Financial Performance as Intervening Variable, Procedia Social and Behavioral Science, 211, $292-298$

35. Ousama, A.A., Fatima, A.H., dan Hafiz, A.R., (2011), Usefullness of Intellectual Capital Information Preparer's and User's Views, Journal of Intellectual Capital, Vol. 12, No. 3, 430 - 445

36. Ozkan, N., Cakan, S., danKayacan, M., (2016), Intellectual Capital and Financial Performance: A Study of Turkish Banking Sector, Borsa Istanbul Review, 1 - 9

37. Popula, J., danVolna, J., (2012), A Content Analysis of Intellectual Capital ReportingWithin Slovak Companies, Prosiding European Conference on Intellectual Capital, Academic Publishing International, Helsinki, 363 - 370

38. Rachmawati, D., Antonio, W.K., danSuwidji, N.E., (2017), Non-Financial Information Has More Value Relevance than Financial Information: Does it?, Prosiding 5th Global Conference on Business and Social Sciences, Kuala Lumpur 4 - 5 Mei 2017, 481 - 487 
39. Sharma, K., danKaur, M., (2016), Web Based Disclosure Practices of Intangible Asset of Selected Indian Companies - an Empirical Study, Imperial Journal of Interdisciplinary Research, Vol. 2, No. 3, 521 - 528

40. Sveiby, K.E, (1997), The Intangible Asset Monitor, Journal of Human Resources Costing and Accounting, Vol. 2, No. $1,73-97$

41. Sveiby, K.E, (2001), Methods for Measuring Intangible Assets, downloaded from: //web.archive.org/web/20011219201230/http://www.sveiby.com/articles/IntangibleMethods.htm

42. Sveiby, K.E, (2010), Methods for Measuring Intangible Assets, downloaded from: www.sveiby.com/articles/IntangibleMethods.htm

43. Uyar, A., danKillic, M., (2012), Value Relevance of Voluntary Disclosure: Evidence from Turkish Firms, Journal of Intellectual Capital, Vol. 13, No. 3, $363-376$

44. Vafei, A., Taylor, D., dan Ahmed, K., (2011), The Value Relevance of Intellectual Capital Disclosure, Journal of Intellectual Capital, Vol. 12, No. 3, $407-429$

45. Wernerfelt B., (1984), A Resource Based View of The Firm, Strategic Management Journal, Vol. 5, No. 2, 171 $-180$ 